\title{
Suppression of Chronic Damage in Renal Allografts by Liver X Receptor (LXR) Activation
}

\section{Relevant Contribution of Macrophage LXR $\alpha$}

Eva Kiss, ${ }^{*}$ Zoran Popovic, ${ }^{*}$ Jens Bedke, ${ }^{*}$ Shijun Wang, ${ }^{*}$ Mahnaz Bonrouhi, ${ }^{*}$ Norbert Gretz, ${ }^{\dagger}$ Paula Stettner, ${ }^{*}$ Daniel Teupser,${ }^{\ddagger}$ Joachim Thiery, ${ }^{\ddagger}$ Stefan Porubsky, ${ }^{*}$ Judith Adams, ${ }^{*}$ and Hermann-Josef Gröne*

From the Department of Cellular and Molecular Pathology,* German Cancer Research Center, Heidelberg; the Medical Research Center, ${ }^{\dagger}$ Klinikum Mannheim, University of Heidelberg, Heidelberg; and the Institute of Laboratory Medicine, ${ }^{\ddagger}$ Clinical Chemistry and Molecular Diagnostics, University of Leipzig, Leipzig, Germany

Liver $X$ receptors (LXR)- $\alpha, \beta$ regulate intracellular cholesterol homeostasis and inhibit inflammatory gene expression. We studied the effects of the LXR $\alpha, \beta$-agonist GW3965 on acute and chronic organ damage in the F344-LEW rat kidney transplantation model. In addition, to gain LXR isoform and cell-specific insights $\mathrm{BALB} / \mathrm{c}$ kidneys were transplanted into mice with macrophage overexpression of LXR $\alpha(\operatorname{mLXR} \alpha$-tg) and evaluated 7 and 42 days after transplantation. After 56 days GW3965 improved significantly function and morphology of rat kidney allografts by substantial reduction of mononuclear cell infiltrate and fibrosis; in vitro GW3965 reduced inflammatory activity of bone marrow-derived macrophages (BMDMs) and alloreactivity of $T$ cells. Kidneys transplanted into mLXR $\alpha$-tg mice were also protected from development of chronic allograft dysfunction. Similarly to GW3965-activated BMDMs, mLXR $\alpha$-tg macrophages secreted significantly less monocyte chemoattractant protein 1 and macrophage inflammatory protein $1 \beta$. Interestingly, 7 days after transplantation, when the total number of intragraft macrophages did not differ, evidently more arginase 1- and mannose receptor $C$ type 1-positive cells were found in LXR rat and mice kidney allografts; in vitro both LXR activation by GW3965 and mLXR $\alpha$ overexpression accentuated the induction of alternative activation of BMDMs by
IL-4/IL-13, suggesting an additional mechanism by LXRs to prevent graft damage. The results highlight the relevance of macrophage LXR $\alpha$ in allograft rejection and prevention of fibrosis. (Am J Pathol 2011, 179:92-103; DOI: 10.1016/j.ajpath.2011.03.019)

Chronic renal allograft dysfunction, characterized by atrophic and fibrotic changes, is thought to be the result of complex interactions between innate and adaptive immune responses and parenchymal cells. ${ }^{1}$ Acting synergistically with lymphocytes, macrophages contribute to both innate and acquired immunity. ${ }^{2,3}$ The contribution of macrophages to the pathogenesis of renal fibrosis is well documented, although, depending on the inflammatory microenvironment, macrophages may change their phenotype and take on an anti-inflammatory, reparative, and matrix remodeling role. ${ }^{3-5}$ Recently, macrophages expressing arginase 1 (Arg1) have been found to reduce T-helper cell 2 (Th2)-mediated liver inflammation and fibrosis. ${ }^{6}$ We have shown that Ccr5 deficiency could induce the alternative activation (M2) pathway in macrophages; the resulting M2 phenotype apparently had an important role in the attenuation of chronic renal allograft rejection. ${ }^{7}$

Liver $X$ receptors (LXRs) are lipid-ligand-activated nuclear receptors. The two LXR isotypes, $\alpha$ and $\beta$, have high-sequence homology and are activated by oxidized cholesterols (oxysterols) or synthetic agonists such as T0901317 or GW3965., ${ }^{8,9}$ LXR $\beta$ is ubiquitously expressed, whereas $\operatorname{LXR} \alpha$ is restricted to certain or-

Supported by grants from the Deutsche Forschungsgemeinschaft SFB 938, G/P (H.-J.G and S.P.), GR 880/3 (H.-J.G.) and EU grant INNOCHEM (H.-J.G.).

Accepted for publication March 17, 2011.

Supplemental material for this manuscript can be found at http://ajp. amjpathol.org or at doi: 10.1016/j.ajpath.2011.03.019.

Address reprint requests to Hermann-Josef Gröne, M.D., Department of Cellular and Molecular Pathology, Im Neuenheimer Feld 280, D-69120 Heidelberg, Germany. E-mail: h.-j.groene@dkfz.de. 
gans and cells such as liver, adrenal glands, intestine, adipose tissue, lung, and kidney. ${ }^{10}$ Macrophages express both LXRs; in lymphocytes the dominating isotype seems to be LXR $\beta .^{11}$

After ligand binding LXRs form permissive heterodimers with the retinoid $X$ receptor. These dimers control transcriptional programs involved in lipid metabolism and inflammation. ${ }^{10,12}$ In murine macrophages ligandactivated LXRs have been shown to blunt the expression of inflammatory genes, such as iNOS, COX-2, and MMP-9, and various chemokines [eg, monocyte chemoattractant protein (MCP)-1] in response to lipopolysaccharide, tumor necrosis factor- $\alpha$, and IL-1 $\beta .{ }^{13-15}$ In RAW cells and primary mouse macrophages $\operatorname{LXR} \alpha$ has been documented to positively regulate arginase II, a gene that may have anti-inflammatory effects through antagonism of nitric oxide signaling. ${ }^{16}$ It has been reported that the transcriptional regulation of intracellular cholesterol homeostasis by LXR $\beta$ influences lymphocyte proliferation and acquired immune responses. ${ }^{11}$ Collectively, these data have led us to expect a relevant immunomodulatory activity of LXRs in chronic fibrosing inflammation, which we exemplarily analyzed in renal allografts with chronic damage.

We have studied the effects of ligand activation of LXRs by GW3965 on acute and chronic rejection phenomena of F344-to Lew rat renal allografts. In addition, we have investigated whether in a fully major histocompatibility complex-mismatched model of mouse renal transplantation the cell-specific transgenic expression of $\mathrm{LXR} \alpha$ in recipient macrophages might affect renal allograft rejection. Our results have shown that the LXR agonist GW3965 could prevent the development of chronic lesions in rat renal allografts by a reduction of the mononuclear cell infiltrate and by reduced intragraft pro-inflammatory/profibrotic gene [MCP-1/CCL2, macrophage inflammatory protein (MIP)-1 $\beta / C C L 4]$ expression. Macrophage $L X R \alpha$ had an important effect on chronic organ damage because kidneys transplanted into mice with selective overexpression of $\mathrm{LXR} \alpha$ in macrophages showed considerably better function and morphology 42 days after transplantation. In addition to the quantitative reduction of the pro-inflammatory macrophage phenotype, we could detect the induction of anti-inflammatory alternatively activated macrophages by LXRs during the acute phase of rejection which may have contributed to prevention of late graft damage.

\section{Materials and Methods}

\section{Animals}

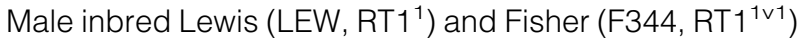
rats as well as BALB/c mice were purchased from Charles River GmbH, Sulzfeld, Germany. Mice with macrophage overexpression of $\mathrm{LXR} \alpha$ (C57BL/6 background) were provided by Daniel Teupser (University of Leipzig, Germany) $)^{17}$ and bred in our animal facility. These mice were designated as $m L X R \alpha$-tg. Animal experiments were performed according to German laws on animal protection.

\section{Kidney Transplantation}

\section{Rats}

Transplantation was performed under ether drop anesthesia. ${ }^{18}$ The left kidney of the donor rat (F344) was isolated, perfused with ice-cold isotonic sodium chloride solution, excised, and transplanted orthotopically into a weight-matched (200 to $220 \mathrm{~g}$ ) Lewis recipient. In the recipient, the left renal vein and artery were mobilized and clamped, the ureter was cut, and the left kidney was excised. End-to-end anastomoses of renal vessels and of ureter, without ureteral stenting, were performed with 10-0 nonabsorbable nylon sutures. Total ischemic time of

Table 1. Sequences of Primers Used for Real-Time RT-PCR Analysis

\begin{tabular}{|c|c|c|}
\hline Gene & Sense & Antisense \\
\hline \multicolumn{3}{|l|}{ Rat } \\
\hline Cyclophilin & 5'-AGGTGAAAGAAGGCATAGC-3' & 5'-TTACAGGGTATTGCGAGCAG-3' \\
\hline MCP-1/CCL2 & $5^{\prime}-$ GCTGACCCCAATAAGGAATG-3' & 5'-GTTGTGGAAAAGAGAGTGGATG-3' \\
\hline$M I P-1 \beta$ & 5'-GCTCTGACCCTCCCACTTC-3' & $5^{\prime}$-ACTCATTGACCCAGGGCTC-3' \\
\hline IL-4 & $5^{\prime}-$ ACGGCAACAAGGAACACCAC- $3^{\prime}$ & $5^{\prime}$-TTCAGACCGCTGACACCTCTAC-3' \\
\hline IL-10 & $5^{\prime}$-CATGGGTCTTGGGAAGAGAA-3' & 5'-GCTTTCGAGACTGGAAGTGG-3' \\
\hline IL-13 & $5^{\prime}$-CATGGTATGGAGCGTGGAC-3' & 5'-GAGGCCTTTTGGTTACAGAGG-3' \\
\hline MRC1 & $5^{\prime}$-AGTGGTCATCGTGGTCCTTC-3' & $5^{\prime}$-AATGACCGCGATGCTCATTCT-3' \\
\hline \multicolumn{3}{|r|}{ ( } \\
\hline GAPDH & $5^{\prime}-$ АСТСССАСТСТТССАССТТС-3' & 5'-GGTCCAGGGTTTCTTTACTCC-3' \\
\hline Tubulin & $5^{\prime}-$ TCTCTCACCCTCGCСTTCTA-3' & $5^{\prime}$-GGGTCCCAGGTCTACGAACA-3' \\
\hline MCP-1/CCL2 & $5^{\prime}-$ ACCAAGCTCAAGAGAGAGG-3' & $5^{\prime}$-ACATTCAAAGGTGCTGAAGAC-3' \\
\hline$M I P-1 \beta$ & $5^{\prime}$-GCTGTTTCTCTTACACCTCC-3' & $5^{\prime}$-ACTCATGTACTCAGTGACCC $-3^{\prime}$ \\
\hline IL-4 & $5^{\prime}-$ TCCACGGATGCGACAAAAAT - 3' & $5^{\prime}$-TTCTTCTTCAAGCATGGAGT-3' \\
\hline$I L-10$ & $5^{\prime}-$ ACCTGGCAAACAAAATGAGG-3' & 5'-CTCTGACCTGCTGTCATGGA-3' \\
\hline IL-13 & $5^{\prime}-$ CTCACTGGCTCTGGGCTTCA-3' & $5^{\prime}-$ CTCATTAGAAGGGGCCGTGG-3' \\
\hline $\operatorname{Arg}-1$ & $5^{\prime}$-ACCACGGCAGTGGCTTTAACC-3' & 5'-GGTTTTCATGTGGCGCATTC-3' \\
\hline$M R C 1$ & 5'-GCGTTGCACATACCTCAAGA-3' & $5^{\prime}$-GCTAAATGATCGCATGCTCA-3' \\
\hline Chi3/3/Ym1 & $5^{\prime}$-GAAGGAGCCACTGAGGTCTG-3' & $5^{\prime}$-CACGGCACCTCCTAAATTGT-3' \\
\hline Fizz1 & $5^{\prime}$-TCCCAGTGAATACTGATGAGA-3' & $5^{\prime}-$ CCACTCTGGATCTCCCAAGA-3' \\
\hline Pdcd1/g2 & $5^{\prime}$-GCCACACGTGAGTTAT- $3^{\prime}$ & $5^{\prime}-$ TTGAACATGCCAAGCT-3' \\
\hline
\end{tabular}


Table 2. Biochemical Data in Experimental Groups

\begin{tabular}{|c|c|c|c|c|c|}
\hline Groups & Cholesterin (mg/dL) & Triglyceride (mg/dL) & GOT (U/L) & GPT (U/L) & ALP $(U / L)$ \\
\hline Control, 56 days & $118.8 \pm 6.7$ & $53.6 \pm 2.9$ & $83.0 \pm 5.0$ & $12.2 \pm 2.2$ & $66.2 \pm 7.8$ \\
\hline GW3965, 56 days & $107.3 \pm 4.7$ & $46.6 \pm 3.6$ & $77.9 \pm 4.7$ & $8.2 \pm 1.1$ & $82.6 \pm 6.3$ \\
\hline WT, 42 days & $128.6 \pm 5.5$ & $74.1 \pm 8.6$ & ND & ND & ND \\
\hline mLXR-tg, 42 days & $117.8 \pm 7.3$ & $72.8 \pm 10.3$ & ND & ND & ND \\
\hline
\end{tabular}

Values are mean \pm SEM

ALP, alkaline phosphatase; GOT, glutamate oxalate transaminase; GPT, glutamate pyruvate transferase; ND, no data.

the donor kidney varied between 30 and 45 minutes. The right kidney was left in place to enhance rejection and damage to the transplant by avoidance of potential endogenous immunosuppressive effects of renal insufficiency and by a reduction of the work load of the transplanted kidney ${ }^{18,19}$; to obtain functional parameters of the graft at the end of the experiments, the right kidney was removed 48 hours before sacrifice. The animals were fed a standard rat chow without or with the synthetic LXR agonist GW3965 (20 mg/kg of body weight/day) ${ }^{12}$ and sacrificed 7 or 56 days after transplantation. The dose of $20 \mathrm{mg} / \mathrm{kg}$ of body weight/day GW3965 corresponds to a dose by which anti-inflammatory effects of the substance have been found. ${ }^{15,20}$

\section{Mice}

Mice (male, 8 to 10 weeks old, 20 to $25 \mathrm{~g}$ ) were anesthetized with Tribromoethanol (Avertin) intraperitoneally. Kidneys from BALB/c $\left(\mathrm{H}-2^{d}\right)$ donor mice were orthotopically transplanted into C57BL/6 $\left(\mathrm{H}-2^{\mathrm{b}}\right)$ wild-type (WT) or $\mathrm{mLXR} \alpha$-tg recipients as described. ${ }^{21}$ Briefly, the abdomen of the donor was opened through a midline incision, the left kidney with its vessels was attached to a segment of the aorta, and the vena cava along with ureter was removed en bloc. The donor aorta and inferior vena cava were then anastomosed end-to-side to the recipient abdominal aorta and inferior vena cava below the level of the native renal vessels, respectively. The native left kidney was removed before revascularization. Donor and recipient ureters were anastomosed at the ureteropelvic junction end to end. The native right kidney was removed after grafting. Mice were sacrificed on day 7 or day 42 after transplantation.

All transplanted kidneys with hydronephrosis, which was evaluated both macroscopically and by light microscopy, were excluded from the experimental groups.

\section{Biochemical Analysis}

For measurements of serum creatinine and albuminuria animals were kept in metabolic cages 24 hours before the end of the experiment. Serum creatinine (enzymatic determination), urea, cholesterol, triglycerides, glutamate-oxalate-transaminase, glutamate-pyruvate-transferase, alkaline phosphatase, and albumin in urine were
A

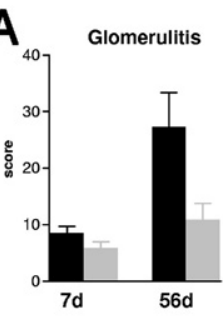

Control-56d

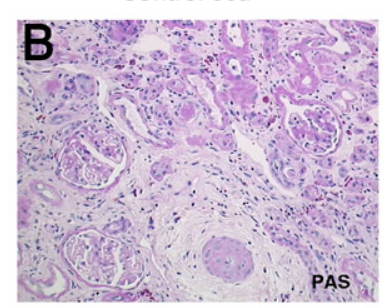

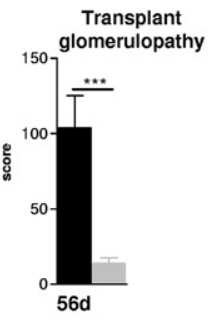

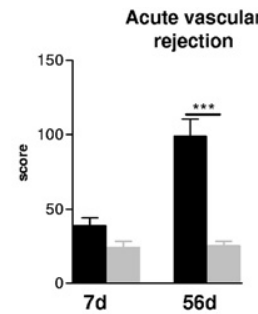

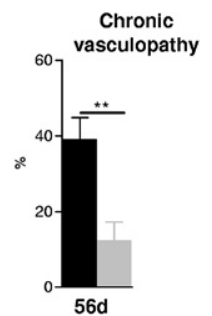
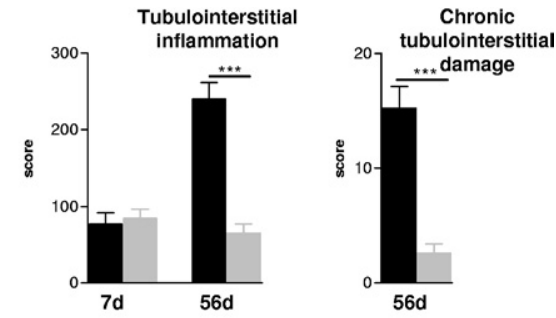

Serum creatinine
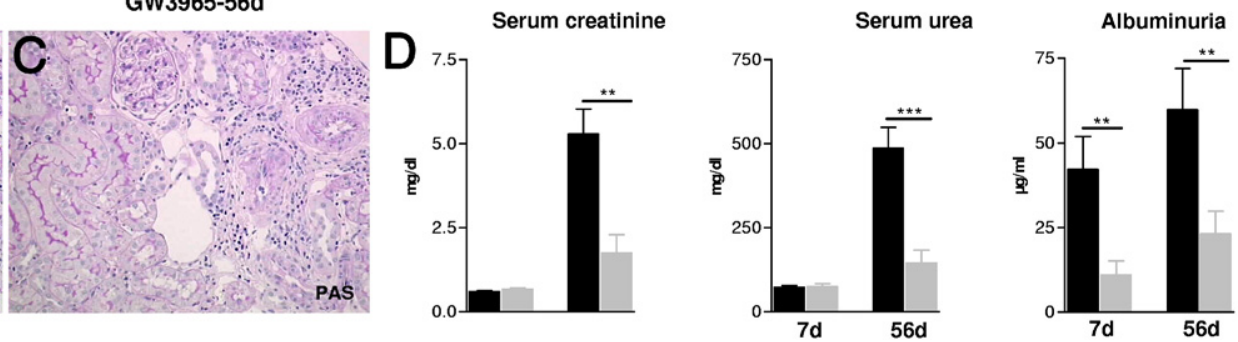

Figure 1. The effects of LXR activation by GW3965 on graft structure and function of Fisher-LEW kidney allografts 7 and 56 days after transplantation. A: Glomerular, vascular, and tubulointerstitial damage scores were significantly reduced 56 days after transplantation by GW3965. No significant differences were detected at day 7 after transplantation. B: Representative micrograph of an untreated renal allograft 56 days after transplantation showing a pre-glomerular artery with significant obliteration by subendothelial matrix increase and perivascular fibrosis, glomeruli with segmental extensive broadening of peripheral basement membrane, and tubulointerstitium with increased interstitial mononuclear cell infiltrate and matrix, surrounding collapsed atrophic tubules. C: Micrograph of an allograft with LXR activation presenting pre-glomerular arteries with only few mononuclear cells sticking to endothelium and moderate perivascular mononuclear cell infiltrate; glomeruli with few mononuclear cells in the capillary lumen, surrounding tubulointerstitium with focal sparse mononuclear cell infiltrate; majority of tubules are differentiated. Original magnification, $\times 200$ (B and C; PAS staining). D: Graphs presenting functional parameters (serum creatinine, urea, albuminuria) of kidney allografts of bilaterally nephrectomized rats, significantly improved 56 days after transplantation by GW3965. Mean \pm SEM; ${ }^{* *} P<0.01,{ }^{* * * * *} P<0.001$ versus controls. 
Glomerull

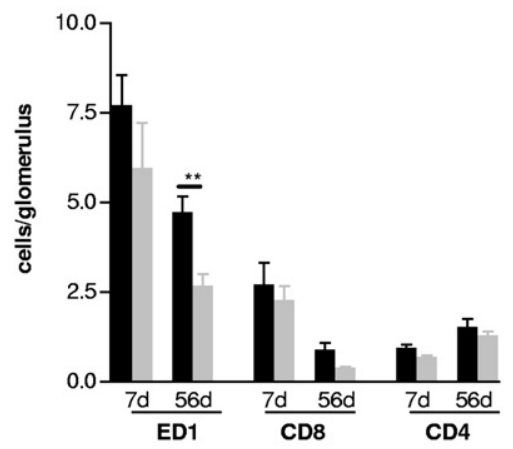

Tubulointerstitium

Control

GW3965
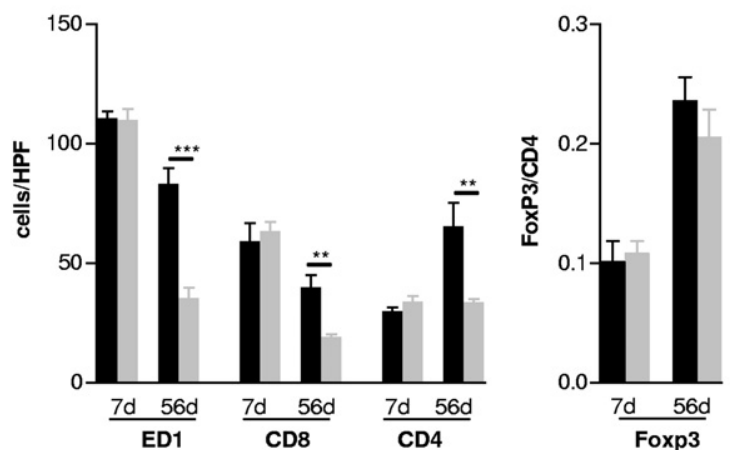

Figure 2. The effects of LXR activation by GW3965 on mononuclear cell infiltrate in rat kidney allografts 7 and 56 days after transplantation. Phenotyping of the mononuclear cell infiltrate of rat kidney allografts by IHC evidenced a significant reduction of ED $1^{+}$macrophages (glomeruli and tubulointerstitium) as well as $\mathrm{CD}^{+}$and $\mathrm{CD}^{+}{ }^{+} \mathrm{T}$ cells in the tubulointerstitial area of kidney allografts 56 days after transplantation by GW3965; the number of FoxP3 ${ }^{+} \mathrm{T}_{\text {cells }}$ was also lower in kidney allografts at this time point. The magnitude of glomerular and tubulointerstitial mononuclear cell infiltrate was not significantly different between controls and GW3965-treated grafts 7 days after transplantation. Mean \pm SEM; ${ }^{* * * *} P<0.01,{ }^{* * * *} P<0.001$ versus controls.

analyzed by a Hitachi 9-17-E autoanalyzer (Hitachi, Frankfurt, Germany).22

\section{Histology}

Renal allografts were removed in deep anesthesia, quickly blotted free of blood, weighed, and processed as required for histology, immunohistology, and molecular analysis. For histology and immunohistology the kidneys were cut into 1-mm coronal slices and immersion fixed in $4 \%$ formaldehyde in PBS, Methacarn (rat kidney samples), or zinc solution (mice kidney samples) and then embedded in paraffin. In addition tissue slices were snap frozen in liquid nitrogen and stored at $-80^{\circ} \mathrm{C}$.

Light microscopy was performed on $3-\mu \mathrm{m}$ sections stained by PAS. Kidneys were evaluated for evidence of acute and chronic vascular, glomerular, and tubulointerstitial damage as previously described. ${ }^{17,23}$ In short, acute vascular injury was assessed as 0 , indicating no injury; 0.5, sticking of mononuclear cells to the endothelium; 1 , subendothelial location of mononuclear cells; 2 , inflammation of the media, including transmural infiltration; or 3, fibrinoid necrosis of the vessel wall or thrombosis of the vessel or both in addition to the inflammatory reaction. Chronic vascular injury was evaluated as negative $(-)$ or positive $(+)$, determined as narrowing of the luminal area by fibrous thickening of the subendothelial space with or without the presence of foam cells and given as percentage of positive vessels. Acute glomerular injury was defined as 0 , indicating no injury; 0.5, sticking of mononuclear cells to the capillary endothelium in $<50 \%$ of the convolutes; 1 , sticking of mononuclear cells
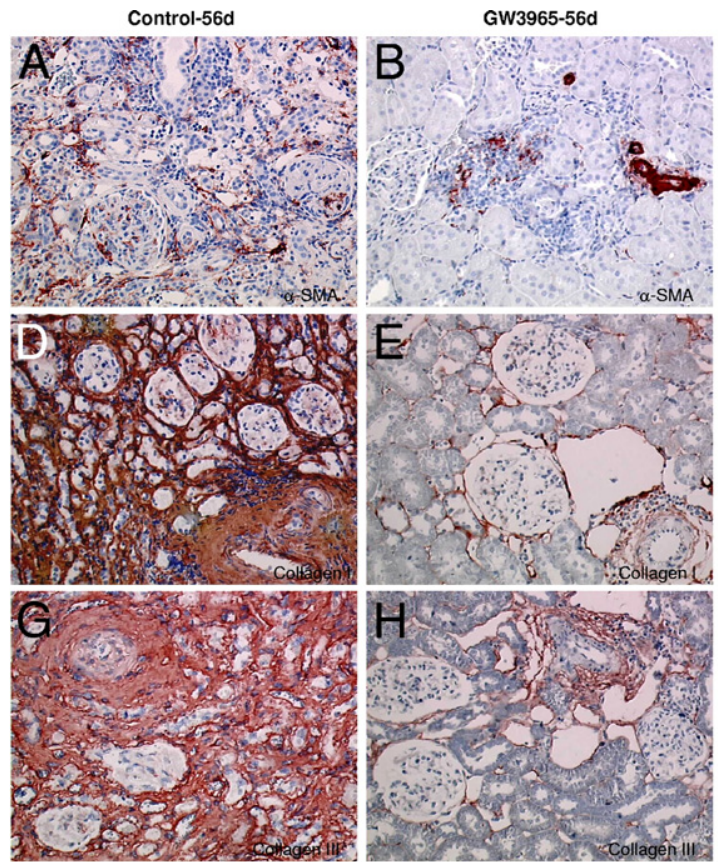
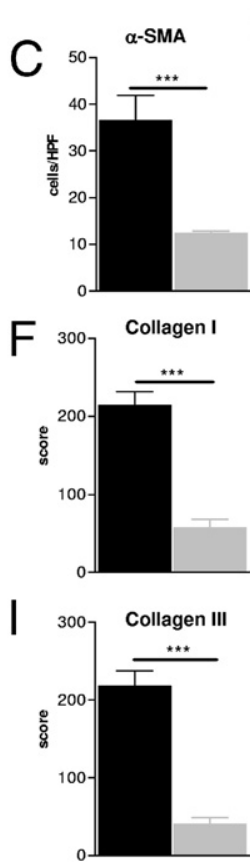

Figure 3. Effects of LXR activation by GW3965 on fibroblasts $(\mathbf{A}-\mathbf{C})$ and extracellular matrix proteins (D-I) in rat kidney allografts 56 days after transplantation. Micrograph showing the high number of $\alpha$-SMA ${ }^{+}$(A) myofibroblasts in an untreated kidney allograft; considerably less $\alpha$-SMA ${ }^{+}$fibroblasts can be seen in GW3965 transplants 56 days after transplantation (B). Diffuse deposition of collagen I (D) and III (G) in the tubulointerstitium of control renal allografts 56 days after transplantation. By GW3965 a significant reduction of tubulointerstitial collagen (E) and III (H) was seen. The results of semiquantitative evaluation (see Materials and Methods) are presented as mean $\pm \mathrm{SEM}$; ${ }^{*} * * * 0.001$ versus controls $(\mathbf{C}, \mathbf{F}$, and $\mathbf{I})$. Original magnification, $\times 200(\mathbf{A}, \mathbf{B}, \mathbf{D}, \mathbf{E}, \mathbf{G}$, and $\mathbf{H}$; avidin biotin complex staining). 
Table 3. Effects of GW3965 on mRNA Expression of Cytokines/Chemokines in Rat Kidney Allografts 56 Days after Transplantation

\begin{tabular}{lccccc}
\hline Groups & IL-4 & IL-10 & IL-13 & MCP-1 & MIP-1 $\beta$ \\
\hline Control & $1.07 \pm 0.2 \times 10^{-2}$ & $0.32 \pm 0.1$ & $0.62 \pm 0.1 \times 10^{-2}$ & $6.79 \pm 2.8$ & $0.20 \pm 0.1$ \\
GW3965 & $0.53 \pm 0.1 \times 10^{-2 \star}$ & $0.11 \pm 0.1$ & $0.27 \pm 0.1 \times 10^{-2}$ & $0.32 \pm 0.3^{*}$ & $0.02 \pm 0.0^{+}$ \\
\hline
\end{tabular}

Values were normalized to cyclophilin mRNA levels and are shown as mean \pm SEM; $n=5$ to 6 animals per group.

${ }^{*} P<0.05$ versus controls.

${ }^{\dagger} P<0.01$ versus controls.

to the capillary endothelium in $>50 \%$ of the convolute; 2 , mesangiolysis with or without sticking of mononuclear cells; or 3, aneurysm, thrombosis, or necrosis of the capillary loops. Chronic glomerular injury was defined as 0 , indicating no sclerosis; 0.5 , sclerosis of $<25 \%$ of capillary loops; 1 , sclerosis of $26 \%$ to $50 \%$ of the capillary loops; 2 , sclerosis of $51 \%$ to $75 \%$ of the capillary loops; or 3 , sclerosis of $>75 \%$ of the capillary loops. The acute and chronic glomerular injury was evaluated in $\geq 50$ glomeruli per sections. Chronic tubulointerstitial damage was defined as broadening of the basement membrane of the tubuli with flattened epithelium, tubular atrophy, and interstitial matrix increase; it was judged as 0.5 , indicating focal chronic damage, and 1 , diffuse chronic damage. Tubulointerstitial inflammation was judged as 0 , indicating no mononuclear cells in the interstitium; 0.5 , focal mononuclear cell infiltration in the interstitium; 1 , focal mononuclear infiltration in the interstitium with tubulitis; 2 , diffuse mononuclear cell infiltration of the interstitium; or 3 , diffuse mononuclear cell infiltration of the interstitium with tubulitis. Tubulitis was defined as $\geq 1$ mononuclear cells/ tubular cross section. A tubulointerstitial inflammation index was defined as the percentage of fields with respective degree of the injury encountered in 10 fields (objective 20x) of cortex and outer stripe of outer medulla. The final tubulointerstitial inflammation score was calculated as the sum of all specific indices, whereby the index of fields with degree 0.5 was multiplied by 0.5 , that of degree $1 \times 1$, that of degree $2 \times 2$, and that of degree $3 \times 3$. Vascular and glomerular injury were scored in an analogous pattern. ${ }^{17,23}$

Morphometric analysis was performed with the use of a semiautomatic image analyzing system (Leica Q600 Qwin, Cambridge, UK) on sections stained with Goldner-Masson-Trichrom to quantify scared areas in tubulointerstitium: 10 randomly selected fields (objective $10 \times$ ) of cortex and outer stripe of outer medulla were evaluated. Results were expressed as a percentage of the total tubulointerstitial area, obtained after exclusion of glomeruli. ${ }^{18}$

\section{IHC}

Immunohistochemical (IHC) staining was done on sections of frozen or paraffin-embedded kidney samples. The antibodies used for rat tissues included mouse antirat monoclonal antibodies against ED1, CD4, CD8 (Serotec, Oxford, UK), Ki-67 (clone MIB-5; Dianova, Hamburg, Germany), rat anti-rat FoxP3 (NatuTec, Frankfurt, Germany), rabbit anti-rat polyclonal antibodies against collagen I (Biogenesis, Poole, UK), collagen III (Chemicon,
Temecula, CA), C4d (Hycult Biotech, Beutelsbach, Germany), and antibodies to $\alpha$-smooth muscle actin ( $\alpha$-SMA) (mouse ascites fluid; Sigma, Schnelldorf, Germany). Mouse kidneys were stained with rat anti-mouse monoclonal antibodies against F4/80 (Serotec), CD3 (Santa Cruz Biotechnology, Santa Cruz, CA), CD4 (BD Biosciences Pharmingen, San Diego, CA), FoxP3 (NatuTec), $\alpha$-SMA (Sigma), and rabbit anti-mouse against collagen I/III (Biogenesis). Anti-Arg1 (BD Biosciences Pharmingen), anti-mannose receptor-1 (CD206; Abcam) monoclonal antibodies were used to detect markers of alternatively activated macrophages.

Positive glomerular cells were counted in $\geq 50$ glomerular cross sections and given as the mean per glomerular section; interstitial positive cells were counted in 20 highpower fields $(\times 40)$ of cortex and outer medulla and re-
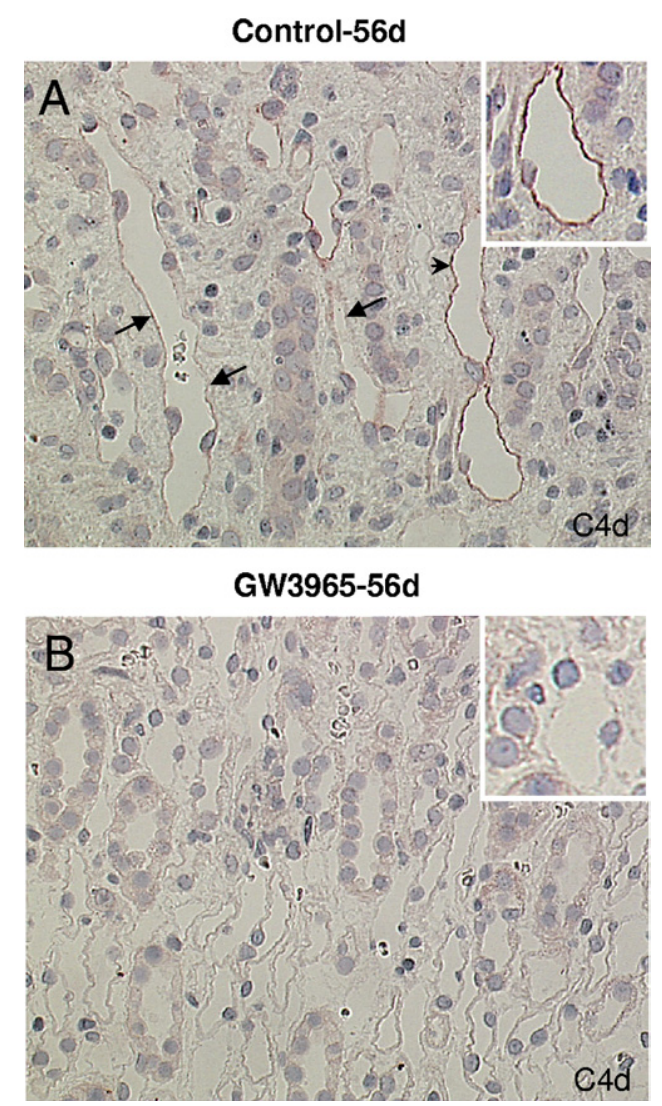

Figure 4. Effects of LXR activation by GW3965 on antibody-mediated rejection in rat kidney allografts 56 days after transplantation. Micrograph showing linear (arrowhead) and granular (arrows) C4d-stained peritubular capillaries in control renal allografts 56 days after transplantation (A). By GW3965 no stained capillaries could be observed (B). Original magnification, $\times 400$ (avidin biotin complex staining). 
corded as mean per high-power field. The intensity of the staining for collagen was evaluated as not detectable (degree 0), faint (degree 1), moderate (degree 2), and intense staining (degree 3 ). Scores were calculated as described. ${ }^{18}$

\section{Bone Marrow-Derived Macrophages}

Generation of murine bone marrow-derived macrophages (BMDMs) of WT and mLXR $\alpha$-tg mice was performed according to standard protocols. ${ }^{24,25}$ In brief, mouse femurs were dissected, and each bone was flushed with $10 \mathrm{~mL}$ of PBS. A bone marrow cell suspension was collected and centrifuged. Pellets were resuspended in RPMI 1640 medium supplemented by 20\% macrophage colony-stimulating factor-containing L929 medium. The cells were plated on non-TC-treated $10-\mathrm{cm}$ petri dishes and incubated at $37^{\circ} \mathrm{C} / 5 \% \mathrm{CO}_{2}$. Fresh medium was provided at days 3 and 5 , and experiments were performed at day 7. After pre-incubation with dimethyl sulfoxide (DMSO; 0.05\%) (WT and $\mathrm{mLXR} \alpha$-tg) or 3 $\mu \mathrm{mol} / \mathrm{L}$ GW3965 dissolved in DMSO (WT) for 16 hours, macrophages were stimulated with murine IL-4 and IL-13 (10 ng/mL; PrepoTech) overnight. Cells and supernatant fluids were collected for further analyses.

\section{Mixed Lymphocyte Reaction}

Splenic $T$ cells and $T$ cell-depleted splenocytes were prepared as described. ${ }^{26}$ Briefly, spleens from BALB/C $(n=4)$ and C57BL/6 mice $(n=4)$ were mechanically disrupted in 6-well plates with $5 \mathrm{~mL}$ of digestion solution [RPMI 1640, $10 \mathrm{mmol} / \mathrm{L}$ HEPES, 0.1\% bovine serum albumin (BSA), $0.5 \mathrm{mg} / \mathrm{mL}$ collagenase $\mathrm{IA}$, and $4.5 \mathrm{kU} / \mathrm{mL}$ DNase I; all from Sigma-Aldrich] and incubated for 15 minutes at $37^{\circ} \mathrm{C}$ and $5 \% \mathrm{CO}_{2}$. After repetitive pipetting, cell suspensions were sieved through filters with $100-\mu \mathrm{m}$ and $30-\mu \mathrm{m}$ pore sizes (BD, Heidelberg, Germany). Purified splenic T cells and T cell-depleted splenocytes were prepared with magnetic bead-coupled anti-CD90.2 antibodies (clone 30-H12; Miltenyi Biotec, Galdbach, Germany) and with magnetically activated cell sorter mass spectrometric columns and separators (both Miltenyi Biotec) according to the manufacturer's instructions. After pretreatment with DMSO $0.05 \%$ or $3 \mu \mathrm{mol} / \mathrm{L}$ GW3965 dissolved in DMSO WT for 16 hours $10^{5} \mathrm{~T}$ cells purified from C57BL/6 mice were incubated with $10^{5} \mathrm{~T}$ cell-depleted splenocytes from BALB/c mice. Culture supernatant fluids were harvested after 24 and 72 hours, and concentrations of IL-2 and interferon- $\gamma$ (IFN- $\gamma$ ) were analyzed as described below.

\section{Cytometric Bead Array for Measurement of Cytokines/Chemokines}

Supernatant fluids of BMDM and splenocyte/T cell cocultures were measured for MCP-1, MIP- $1 \beta$ and IL-2, and IFN- $\gamma$, respectively, by FACSCalibur with BD CBA FlexSet bead assays (BD). Sample files were analyzed by FCAP Array 1.0.1 software.

\section{RNA Extraction and Real-Time RT-PCR}

Total RNA was extracted from the kidney allografts and macrophages (BMDMs) with the method of Chomczynski

\section{A}
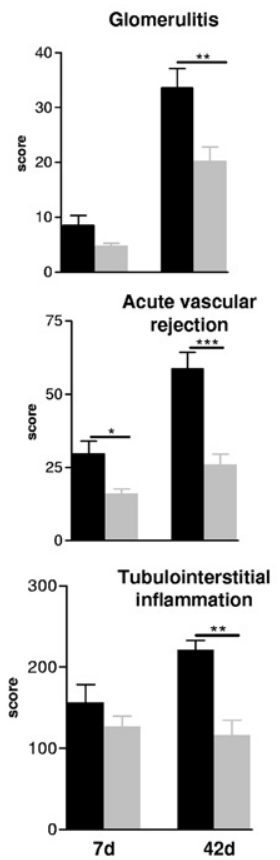

WT-42d
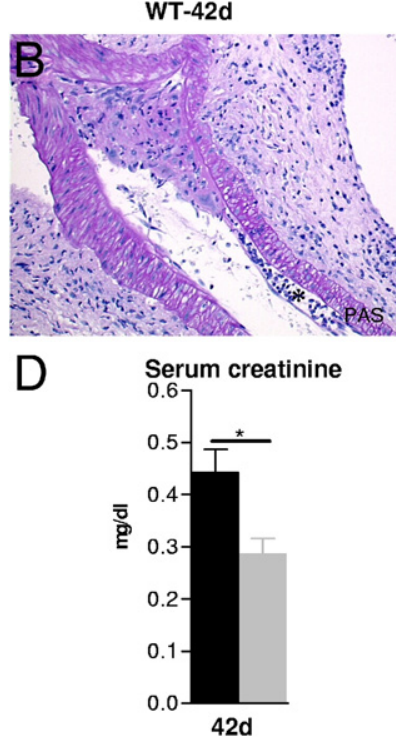
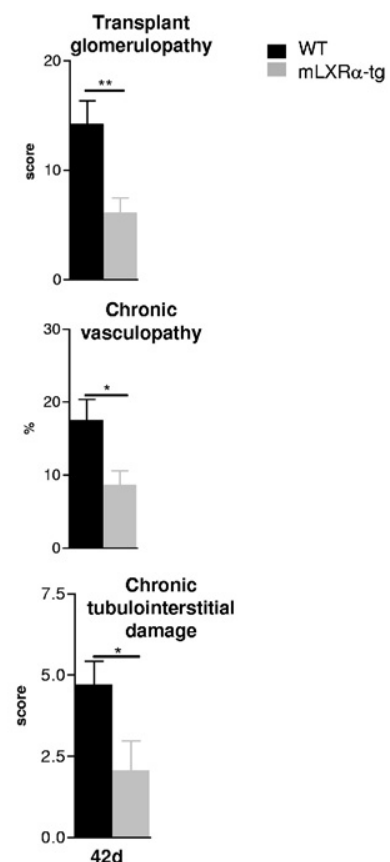

$\mathrm{mLXR} \alpha-\operatorname{tg}-42$
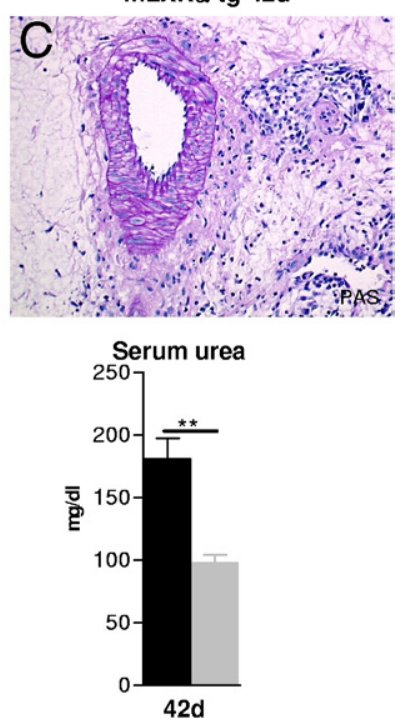

Figure 5. The effects of $\mathrm{LXR} \alpha$ overexpression in recipient macrophages $(\operatorname{mLXR} \alpha-\operatorname{tg})$ on structure $(\mathbf{A}-\mathbf{C})$ and excretory function $(\mathbf{D})$ of mice renal allografts 7 and 42 days after transplantation. A: Significant amelioration of acute and chronic glomerular, vascular, and tubulointerstitial changes in kidney allografts of $\operatorname{mLXR} \alpha$-tg recipients in comparison to grafts of WT recipients 42 days after transplantation. Mean $\pm \mathrm{SEM} ;{ }^{*} P<0.05$, ${ }^{*}{ }^{*} P<0.01$, and ${ }^{* * * *} P<0.001 \mathrm{mLXR} \alpha$-tg versus WT. B: A pre-glomerular artery of a graft transplanted into WT recipient showing an important constriction of the vessel lumen by a subendothelial mononuclear cell infiltrate and matrix increase. Subendothelial foam cells also can be observed (asterisk). Important perivascular fibrosis with mononuclear cell infiltrate. C: Regular aspect of a pre-glomerular artery of a graft transplanted into $\operatorname{mLXR} \alpha$-tg recipient Perivascular fibrosis and mononuclear cell infiltrate are reduced. D: Graft excretory functional parameters (serum creatinine, urea) of $\operatorname{mLXR} \alpha$-tg recipients were significantly lower compared with grafts of WT recipients 42 days after transplantation. Mean $\pm \mathrm{SEM} ;{ }^{*} P<0.05,{ }^{* *} P<0.01 \mathrm{mLXR} \alpha$-tg versus WT. Original magnification: $\times 200(\mathbf{B}$ and $\mathbf{C}$; PAS staining). 
Glomeruli

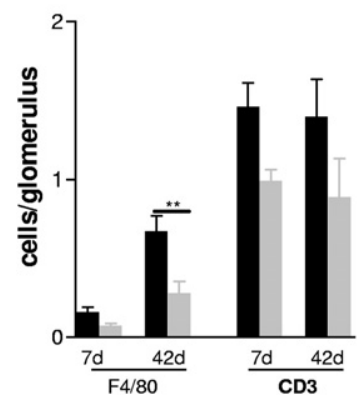

Tubulointerstitium

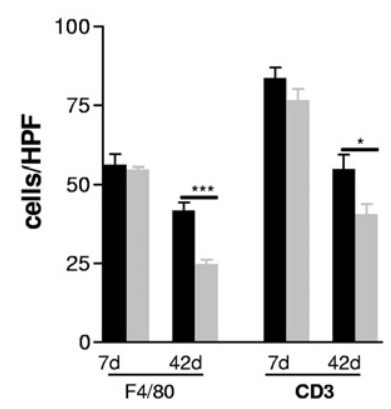

- WT $\mathrm{mLXR} \alpha-\operatorname{tg}$

Figure 6. Effects of LXR $\alpha$ overexpression in re-

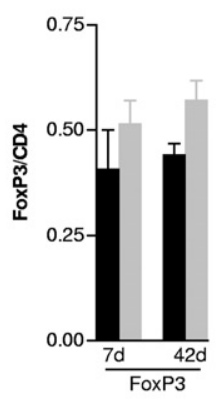
cipient macrophages (mLXR $\alpha$-tg) on mononuclear cell infiltrate of mice renal allografts 7 and 42 days after transplantation. Graphs presenting a significant reduction of $\mathrm{F} 4 / 80^{+}$macrophages (glomeruli and tubulointerstitium) and $\mathrm{CD}^{+}{ }^{+} \mathrm{T}$ cells (tubulointerstitium) in mice kidney allografts of $\operatorname{mLXR} \alpha$-tg recipients 42 days after transplantation in comparison to graft of WT recipients. The number of interstitial FoxP $3^{+} \mathrm{T}$ cells did not change in grafts of $\operatorname{mLXR} \alpha$-recipients Mean \pm SEM; ${ }^{*} P<0.05,{ }^{* * *} P<0.01$, and ${ }^{* * * *} P<$ $0.001 \mathrm{mLXR} \alpha$-tg versus WT.

and Sacchi $^{27}$ ( $n=$ four to six animals/group). RNA quality was checked by a RNA6000 Nanochip (Agilent Technologies, Waldbronn, Germany). Total RNA (10 $\mu \mathrm{g}$ ) was digested with DNase I according to standard protocol. Total RNA (3 $\mu \mathrm{g}$; DNA free) was used for the first-strand cDNA synthesis with the use of Superscript II Reverse Transcriptase and oligo d(T)12-18 as primer (LifeTechnologies, Karlsruhe, Germany). Real-time PCR was performed by LightCycler with the use of LightCyler-FastStart DNA MasterSYBR Green I kit (Roche Diagnostics, Mannheim, Germany) as described. ${ }^{18}$ The primer sequences for target genes are shown in Table 1.

\section{Statistical Analysis}

All data were presented as mean \pm SEM. Data were analyzed by the non-parametric Mann-Whitney U-test or unpaired $t$-test as appropriate. A $P$ value $<0.05$ was considered to show a significant difference between two groups.

\section{Results}

\section{Plasma Lipid Levels and Hepatic Enzyme Activities}

At day 7 after transplantation treatment with GW3965 led to a moderate increase of triglyceride levels (data not shown). As presented in Table 2, at day 56 after transplantation no significant differences in triglyceride and cholesterol levels between groups were found, but GW3965 led to an increase of alkaline phosphatase activity, a phenomenon previously reported. ${ }^{28}$ Consistent with earlier data in mice with overexpression of $\mathrm{LXR} \alpha$ in macrophages, plasma lipids did not change in comparison to WT littermates. ${ }^{17}$

\section{Ligand Activation of LXR by GW3965 Prevents Chronic Allograft Dysfunction in F344-LEW Kidney Grafts}

Administration of GW3965 for 7 days after transplantation led to a moderate reduction of glomerular and vascular rejection scores in kidney allografts without reaching sta-

tistical significance (Figure 1A). As presented in Figure 1 graft structure and function deteriorated dramatically between day 7 and day 56 in untreated animals. At day 56 after transplantation vascular and glomerular changes, as well as interstitial inflammation, fibrosis, and tubular atrophy, were strikingly lower in rats with the LXR agonist (Figure 1, A and C). Graft excretory functional parameters serum creatinine, urea, and albuminuria were approximately threefold lower, showing a significantly improved renal function in comparison to rats without LXR activation (Figure 1D).

At day 7 the number of graft-infiltrating mononuclear cells did not differ between controls and GW rats (Figure 2). In contrast, at day 56 after transplantation the mononuclear cell infiltrate consisting of ED1 ${ }^{+}$macrophages $(\Delta 50 \%), \mathrm{CD}^{+}$and, to a lesser extent, $\mathrm{CD}^{+} \mathrm{T}$ lymphocytes ( $\Delta 50 \%$ to $60 \%$ in tubulointerstitium) was significantly diminished by administration of the LXR agonist (Figure 2). The $\mathrm{FoxP}^{+}$subpopulation of $\mathrm{CD}^{+}{ }^{+} \mathrm{T}$ cells was not significantly different neither at day 7 nor at day 56 after transplantation between treated and untreated grafts (Figure 2). Given the ability of LXRs to modulate cell proliferation, $, 29,30$ we performed immunostaining for Ki-67. Significantly less proliferating cells were found by LXR-agonist in the interstitial area of kidney grafts 56 days after transplantation (control versus GW: $31.5 \pm 5.3$ versus $6.3 \pm 0.6$ cells/high-power field of interstitium; $P<0.001$ )

Myofibroblasts $\left(\alpha-\mathrm{SMA}^{+}\right)$in the interstitium of kidney allografts decreased significantly with $L X R$ activation for 56 days (Figure $3, A-C$ ). Interstitial fibrosis evaluated by Goldner-Masson-Trichrom was up to sixfold lower (control versus GW: $49.5 \% \pm 1.5 \%$ versus $8.2 \% \pm 2.1 \%$ of interstitium; $P<0.01$ ); in addition, the extracellular matrix

Table 4. Myofibroblasts and Collagen Deposition in Kidney Allografts of $\operatorname{mLXR} \alpha$-tg and WT Recipients 42 Days after Transplantation

\begin{tabular}{lcc}
\hline Groups & $\alpha$-SMA (cells/HPF) & Collagen I/III (score) \\
\hline WT & $16.8 \pm 2.4$ & $171.6 \pm 12.6$ \\
mLXR $\alpha$-tg & $10.2 \pm 1.7^{\star}$ & $94.3 \pm 12.0^{\dagger}$ \\
\hline
\end{tabular}

Values are mean \pm SEM.

${ }^{\star} P<0.05$ versus controls.

${ }^{\dagger} P<0.01$ versus controls

$\mathrm{HPF}$, high-power field. 
Table 5. Effects of LXR $\alpha$ Overexpression in Macrophages on mRNA Expression of Cytokines/Chemokines in Mouse Kidney Allografts 42 Days after Transplantation

\begin{tabular}{lccccc}
\hline \multicolumn{1}{c}{ Groups } & $\mathrm{IL}-4$ & $\mathrm{IL}-10$ & $\mathrm{IL}-13$ & $\mathrm{MCP}-1$ & $\mathrm{MIP}-1 \beta$ \\
\hline WT & $0.11 \pm 0.0 \times 10^{-2}$ & $0.35 \pm 0.1 \times 10^{-2}$ & $0.77 \pm 0.1 \times 10^{-3}$ & $1.71 \pm 0.6 \times 10^{-2}$ & $0.03 \pm 0.0$ \\
$\mathrm{mLXR} \alpha-\mathrm{tg}$ & $0.02 \pm 0.0 \times 10^{-2 *}$ & $0.22 \pm 0.1 \times 10^{-2}$ & $0.88 \pm 0.2 \times 10^{-3}$ & $0.16 \pm 0.1 \times 10^{-2 \dagger}$ & $0.01 \pm 0.0^{*}$ \\
\hline
\end{tabular}

Values were normalized to mRNA expression of GAPDH and are shown as mean $\pm \mathrm{SEM} ; n=4$ to 6 animals per group.

${ }^{*} P<0.05$ versus controls.

${ }^{\dagger} P<0.01$ versus controls.

components collagen I and III were reduced threefold to fourfold by the LXR agonist (Figure 3, D-I).

The mRNA expression of IL-4, IL-10, IL-13, MCP-1, and MIP- $1 \beta$ were analyzed by real-time RT PCR. Severn days after transplantation there were no significant differences in the intragraft mRNA expression levels of these cytokines/chemokines with the exception of IL-13, which was significantly higher (see Supplemental Table S1 at http:// ajp.amjpathol.org). At day 56 cytokine expression was significantly lower in the allografts treated with LXR agonist, further showing the relevant reduction of inflammation and fibrosis in these kidneys (Table 3).

$\mathrm{IHC}$ for C4d was performed to test whether the LXR stimulation by GW3965 could modulate the antibodymediated rejection in rat kidney allografts. An evident linear or granular positivity of both of peritubular capillaries could be observed in control allografts 56 days after transplantation; this was almost totally missing in GW3965 transplants (Figure 4).

\section{Overexpression of $L X R \alpha$ in Recipient Macrophages ( $m L X R \alpha$-tg) Is Associated with Reduced Damage in Kidney Allografts}

To study the role of macrophage $\mathrm{LXR} \alpha$ in allograft rejection kidneys of BALB/c mice were transplanted into recipients with transgenic overexpression of $\mathrm{LXR} \alpha$ in macrophages ( $\mathrm{mLXR} \alpha$-tg). Transgenic animals have been shown to express selectively and increased levels of $\mathrm{LXR} \alpha$ in macrophages and brain. ${ }^{17}$

In this fully major histocompatibility complex-mismatched model of renal transplantation characteristic features of acute (7 days after transplantation) and chronic (day 42) damage have developed. ${ }^{7,21}$ Histologic evaluation showed a moderate amelioration of acute glomerular and vascular rejection at day 7 but a significant reduction of all acute $(P<0.001)$ and chronic $(P<0.05)$ rejection scores in kidney grafts of $\mathrm{mLXR} \alpha$-tg recipients at day 42 after transplantation (Figure 5, A-C). Fibrosis was reduced (GoldnerMasson-Trichrom-stained kidney sections: WT versus $\mathrm{mLXR} \alpha$-tg, $19.9 \% \pm 2.6 \%$ versus $7.3 \% \pm 1.0 \%$ of interstitium; $P<0.05)$. Correspondingly, serum creatinine and urea were significantly lower (Figure 5D).

A relevant decrease of $\mathrm{F} 4 / 80^{+}$macrophages was detected in $\mathrm{mLXR} \alpha$-tg recipients at day 42 after transplantation $(P<0.01$ for glomeruli; $P<0.001$ for interstitium; Figure 6$)$. The number of interstitial $\mathrm{CD}^{+}$Iymphocytes was also significantly lower in comparison to grafts of WT recipients (Figure 6 ). The $\alpha$-SMA ${ }^{+}$myofibroblasts and collagen $\mid / I I I$ were found to be significantly less expressed in $\mathrm{mLXR} \alpha$-tg recipients (Table 4).

Seven days after transplantation IL-4, IL-10, and IL-13 mRNA expression levels were higher in grafts of $\mathrm{mLXR} \alpha$-tg recipients (see Supplemental Table S2 at $h$ ttp:// ajp.amjpathol.org). At day 42 after transplantation, corresponding to the overall attenuated inflammation, both the mRNA expression of Th1 and Th2 response-associated pro-inflammatory genes (IL-4, MCP-1, MIP-1 $\beta$ ) was significantly lower in kidneys of $\mathrm{mLXR} \alpha$-tg recipients in comparison to grafts of WT recipients. No statistically significant differences were noted in the expression of IL-10 and $\mathrm{IL}-13$ at this time point (Table 5).

\section{Reduced Inflammatory Activity of BMDMs by LXRs}

It has been reported that ligand activation of LXRs in macrophages dampens its inflammatory phenotype. ${ }^{14-16}$ To test whether similar changes can be observed also in macrophages overexpressing $\mathrm{LXR} \alpha$, we measured the secretion of classical mediators of inflammation in the supernatant fluid of BMDMs of $\mathrm{mLXR} \alpha$-tg mice. In parallel BMDMs pretreated with GW3965 were analyzed. Similarly to macrophages with GW3965, $\mathrm{mLXR} \alpha$-tg macrophages secreted significantly less MCP-1 and MIP-1 $\beta$ (Figure 7).
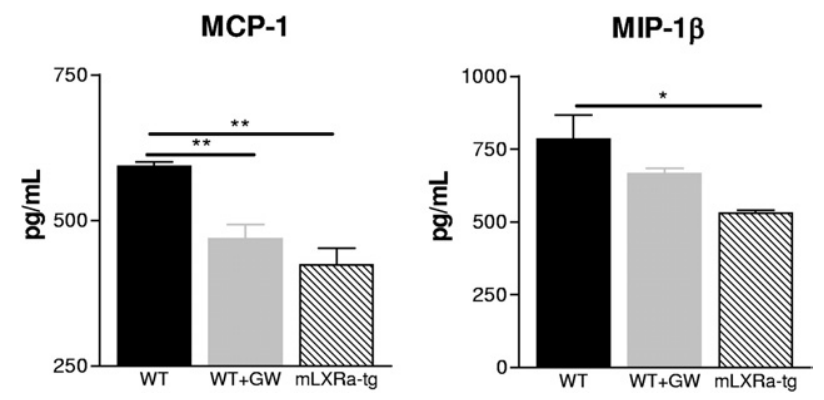

Figure 7. In vitro effects of GW3965 and LXR $\alpha$ overexpression on inflammatory activity of BMDMs. BMDMs were pre-incubated with DMSO (WT and mLXR $\alpha$-tg) or $3 \mu \mathrm{mol} / \mathrm{L}$ GW3965 dissolved in DMSO (WT) for 16 hours. Both GW3965 treatment and LXR $\alpha$ overexpression resulted in secretion of significantly lower amounts of MCP-1 and MIP- $1 \beta$ after 12 hours. Bar diagrams show mean values \pm SEMs for three different experiments; ${ }^{*} P<0.05,{ }^{* * *} P<$ 0.01 versus WT. 


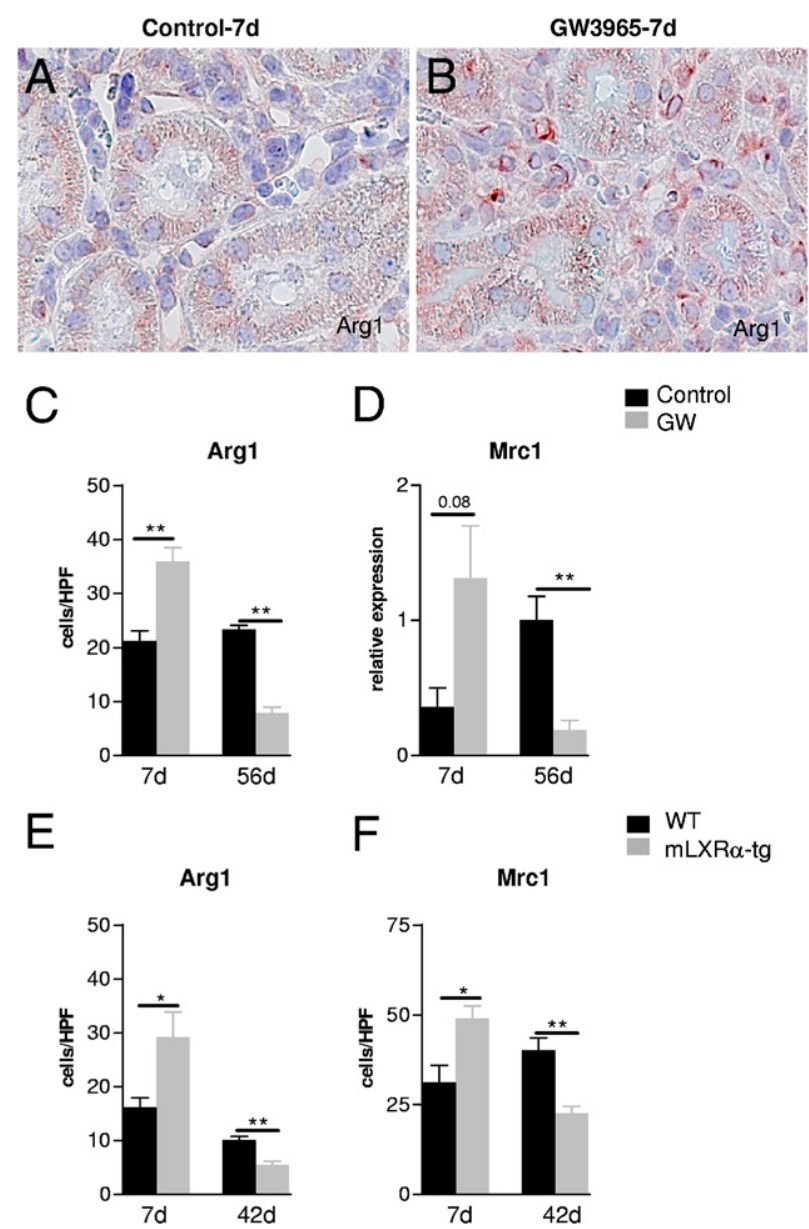

Figure 8. Effects of LXR activity on markers of alternatively activated macrophages in kidney allografts. A higher number of $\operatorname{Arg} 1^{+}$cells in a rat kidney allograft with GW3965 (B) in comparison to an untreated graft (A) 7 days after transplantation. Quantification of $\operatorname{Arg} 1^{+}$cells $(\mathbf{C})$ and the mRNA expression of the M2 marker gene Mrc1 (D) in rat kidney allografts 7 and 56 days after transplantation without and with GW3965. Number of $\operatorname{Arg} 1^{+}$(E) and $\mathrm{Mrc1}^{+}$cells $(\mathbf{F})$ in mouse kidney allografts of WT and $\operatorname{mLXR} \alpha$-recipients 7 and 42 days after transplantation. Note that the total macrophage population at day 7 after transplantation is similar in the control and GW groups but strongly reduced only in LXR rat and mouse kidney allografts at days 56 and 42 , respectively. Mean \pm SEM cells/high-power field. ${ }^{*} P<0.05 \mathrm{GW}$ versus controls; ${ }^{* * *} P<0.01 \mathrm{mLXR} \alpha$-tg versus WT. mRNA expression of Mrc1 in rat kidney allografts was normalized to cyclophilin mRNA (real-time RT-PCR).

\section{Markers of Alternative Macrophage Activation Induced by LXRS}

Markers of alternatively activated macrophages were evaluated by $\mathrm{IHC}$ and real-time RT-PCR in vivo and in vitro. A significant increase in the number of interstitial $\mathrm{Arg}^{+}$cells and an evident increase in the mRNA expression of mannose receptor C type 1 (Mrc1) was found in GW3965-treated rat allografts 7 days after transplantation (Figure 8). This could be of functional relevance because at this time point no differences in the number of intragraft ED1 ${ }^{+}$macrophages between untreated and treated grafts were found. Consonant with the overall reduction of monocytes/macrophages at day 56 by GW3965, Arg $1^{+}$interstitial macrophages were also decreased in number at this chronic stage after transplantation (Figure 2, and Figure 8, A-D). A similar expression pattern was observed in kidney allografts of mice with the macrophage-specific $\operatorname{LXR} \alpha$ transgene: 7 days after transplantation $\mathrm{Arg}^{+}$and $\mathrm{Mrc}^{+}$cells were significantly more numerous, whereas the number of overall $\mathrm{F} 4 / 80^{+}$macrophages remained unchanged. Forty-two days after transplantation parallel to the reduced number of $\mathrm{F} 4 / 80^{+}$macrophages the number of cells positive for markers of alternative activation (Arg1, Mrc1) was significantly lower in grafts of $m L X R \alpha$-tg recipients (Figure 8, E and F). In vitro in BMDM GW3965 accentuated IL-4 and IL-13 induced M2 marker genes Arg1, Mrc1, chitinase 3-like 3 (Chi3l3/Ym1), found in inflammatory zone 1 (Fizz1) and programed cell death 1 ligand 2 (Pdcd1lg2). This effect depended on the LXR $\alpha$ isoform because $L X R \alpha$-tg macrophages showed similar alternative activation of macrophages as those activated by the general LXR ligand, GW3965 (see Supplemental Figure S1 at $h$ ttp://ajp.amjpathol.org).

\section{Reduced T-Cell Response to Alloantigens by LXRs in Vitro}

In addition to macrophages lymphocytes are prominent players of allograft rejection and might be targets of the LXR agonist. To test the effects of LXR stimulation on the reactivity of $T$ cells in an alloantigen mixed lymphocyte reaction, $T$ cell-depleted splenocytes from BALB/c mice were co-cultured with $T$ cells purified from spleens of C57BL/6 mice. GW3965-pretreated T cells secreted significantly lower amounts of IL-2 and IFN- $\gamma$ as measured in the cell-culture supernatant fluids after 24 and 72 hours of co-incubation (Figure 9).

\section{Discussion}

The Fisher 344 to Lewis rat renal transplantation model is a model of allograft rejection between rat strains differing in minor histocompatibility antigens This transplantation model has been shown to exhibit several features of chronic allograft damage encountered in human allo-
IL-2

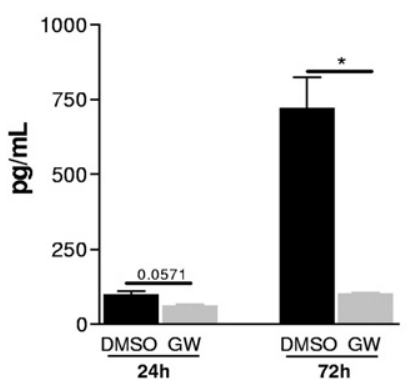

IFN $\gamma$

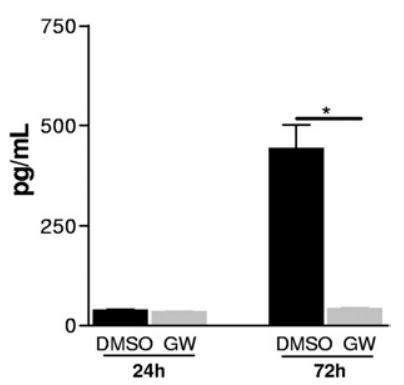

Figure 9. In vitro effects of LXR activation by GW3965 on T-cell response to alloantigens. Mixed lymphocyte reaction was performed with co-incubating $\mathrm{T}$ cell-depleted splenocytes from BALB/c mice with $\mathrm{T}$ cells purified from spleens of C57BL/ 6 mice. GW3965-pretreated T cells ( $3 \mu \mathrm{mol} / \mathrm{L}$ for 16 hours) secreted significantly lower amounts of IL- 2 and IFN- $\gamma$, as measured in the cell culture supernatant fluids after 24 and 72 hours co-incubation. Mean \pm SEM; $n=4 ;{ }^{*} P<0.05$ versus DMSO. 
grafts treated with immunosuppressants and thereby lacking the full alloreactivity of an untreated major histocompatibility mismatched graft. ${ }^{18,31,32}$ Macrophages constitute a major fraction of mononuclear cells in the chronic phase of this model comparable to the high number of macrophages in human renal transplants with transplant glomerulopathy and chronic tubulointerstitial damage. ${ }^{3,18}$ LXR activation by the synthetic agonist GW3965 administered for 56 days after transplantation inhibited the development of advanced chronic changes in rat kidney grafts; graft excretory function was correspondingly preserved. The significant improvement of chronic damage by LXR activation was associated with an important decrease of the mononuclear cell infiltrate.

Studies have characterized LXRs as key regulators of macrophage function. ${ }^{14-16}$ Macrophage accumulation in the transplanted kidney, through recruitment of blood monocytes and subsequent proliferation within the graft, typically precedes and accompanies fibrosis of the grafted organ. ${ }^{1,3}$

Administration of GW3965 for 56 days reduced infiltrating monocytes/macrophages $\left(\mathrm{ED} 1^{+}\right)$in the tubulointerstitium of rat kidney allografts by $60 \%$ and diminished the intragraft expression of pro-inflammatory/profibrotic genes (eg, MCP-1, MIP-1 $\beta$ ). Correspondingly to these in vivo data and in accordance with earlier reports, in BMDMs, treatment with GW3965 reduced the secretion of MCP-1 and MIP- $1 \beta$. These data show that a suppressed inflammatory response of intragraft macrophages by LXR activation might be an important mechanism in prevention of graft fibrosis. The regulation of inflammatory signaling by LXRs in macrophages is thought to be mainly mediated by transrepression. ${ }^{15} \mathrm{Li}$ gand activation of LXRs in murine macrophages has been shown to inhibit the induction of inflammatory genes (eg, iNOS, IL-1 $\beta$, MCP-1) in response to lipopolysaccharide or cytokines (IL-1 $\beta$ and tumor necrosis factor- $\alpha$ ) in part via blockade of NF- $\kappa \mathrm{B}$ signaling. ${ }^{13,15}$ In addition to macrophages the number of intragraft $\mathrm{CD}^{+}$and $\mathrm{CD} 8+$ $T$ cells was also significantly lower in the LXR group on day 56 after transplantation. These effects may involve a diminished T-lymphocyte activation and proliferation in kidney allografts by the LXR agonist. Performing a mixed lymphocyte reaction we found a reduced alloreactivity of GW3965-pretreated T cells. Bensinget et al ${ }^{11}$ could show that $L X R \beta$ is an intrinsic regulator of lymphocyte proliferation. By altering cellular sterol content through the cholesterol transporter, ATP-binding cassette transporter G1 (ABCG1), an LXR target gene, loss of LXR $\beta$ expression increased the proliferative capacity of lymphocytes, leading to enhanced homeostatic and antigen-driven responses; the opposite was observed by ligand activation of the receptor. ${ }^{11}$ In addition, vascular cells might have been affected. BIaschke et $\mathrm{al}^{33}$ have shown that LXR ligands suppress proliferation of vascular smooth muscle cells by the suppression of mitogen-induced degradation of the cyclin-dependent kinase inhibitor; this mechanism may have contributed to the reduced severity of chronic graft vasculopathy in GW3965-treated allografts. Thus, the prevention of fibrotic changes in rat kidney allo- grafts by the nonselective LXR agonist is likely to be a suppression of activity of $T$ cells, monocytes/macrophages, and resident renal cells. In addition, a damped antibody response by GW3965, evidenced by reduced $\mathrm{C} 4 \mathrm{~d}$ immunostaining, can also be considered to contribute to the beneficial effects of LXR activation in chronic kidney allograft rejection.

To investigate which LXR isoform is important for the modulation of macrophage activity in chronic allograft dysfunction, kidneys were transplanted into mice with selective overexpression of $\mathrm{LXR} \alpha$ in macrophages $(\mathrm{mLXR} \alpha$-tg). In an earlier study we have demonstrated that macrophage overexpression of $\operatorname{LXR} \alpha$ achieved by transgenic expression of the mouse $\operatorname{LXR} \alpha$ cDNA under the control of a chicken lysozyme promoter resulted in the activation of $\mathrm{LXR} \alpha$ target genes (ABCA1, ABCG1). ${ }^{17} \mathrm{Ac}$ tivated macrophages can produce higher amounts of endogenous ligands of LXRs [eg, 24(S)-hydroxycholesterol, 22(R)-hydroxycholesterol, 24(S),25-epoxycholesterol], which in the state of overexpressed receptor apparently lead to a biologically relevant activation without further administration of an exogenous ligand. ${ }^{34-36} \mathrm{Be}-$ cause the majority of kidney injury-associated macrophages are derived from the circulating monocyte pool, ${ }^{37}$ these experiments provided cell- and LXR isoform-specific information about LXR signaling in allograft rejection. These data about isoform-specific effects of LXRs are of practical interest for the generation of isoform-specific pharmacologic modulators without potential adverse metabolic effects (hypertriglyceridemia) ascribed to nonselective agonists.

In this fully major histocompatibility complex-mismatched mouse transplantation model kidney allografts of recipients with $\mathrm{LXR} \alpha$ overexpression in macrophages had significantly reduced chronic graft damage shown by a strongly lowered $\mathrm{F} 4 / 80^{+}$macrophage, moderately lowered $\mathrm{CD}^{+}$lymphocytic intragraft infiltrate, and by less fibrosis. The lower expression of MCP-1, MIP- $1 \beta$, and IL-4 reflected reduced Th1 and Th2 responses in the grafts of $m L X R \alpha$-tg mice at day 42 after transplantation. In vitro, similarly to the GW3965-treated BMDMs, macrophages of the transgenic mice secreted less MCP-1 and MIP- $1 \beta$. These results clearly pointed to a blunted pro-inflammatory macrophage phenotype by macrophage $\operatorname{LXR} \alpha$.

Chronic allograft dysfunction might involve not only a sustained pro-inflammatory reaction but also a failure of anti-inflammatory control mechanisms. ${ }^{1,2}$ The prevention of late chronic changes in rat renal allograft by GW3965 without reduction of the degree of mononuclear cell infiltrate in the early phase of rejection raised the question of whether LXR activation modulated the phenotype of the mononuclear cell infiltrate at this time point. Treg-mediated immunosuppression is an unlikely explanation for the improved late graft histology and function, because Foxp $^{+} \mathrm{T}$ cells in renal allografts were not significantly different at day 7 after transplantation between the two groups and were even lower in grafts with GW3965 at day 56. Macrophages can switch from a classically activated state (M1) to an alternatively activated state (M2) on specific signals. ${ }^{4,38} \mathrm{M} 2$ cells can generate Arg1, which 
suppresses inflammation by inhibiting the production of pro-inflammatory nitric oxide. ${ }^{38,39}$ Moreover, Arg1-expressing macrophages have been shown to suppress Th2 cytokine-driven liver inflammation and fibrosis; these effects were independent of $\mathrm{IL}-10$ and transforming growth factor $\beta 1$ and could be correlated to inhibited T-cell proliferation by Arg1-expressing macrophages in vitro. ${ }^{6}$ We have recently found a correlation of improved chronic renal transplantation outcome to alternative macrophage activation in kidney allografts of CCR5-deficient recipients. ${ }^{7}$ These data suggested an until now unappreciated role of alternatively activated macrophages in reduction of chronic renal injury. The higher number of Arg1- and Mrc1-expressing cells by LXR activation in kidney allografts 7 days after transplantation led us to assume that LXR might modulate the induction or activation of alternatively activated macrophages. With the use of IL-4- and IL-13- stimulated BMDMs, we have found the M2 marker genes (Arg1, Mrc1, Ym1, Fizz1, Pdcd1lg2) up-regulated in GW3965-treated as well as LXR $\alpha$ transgene macrophages. In addition, the higher expression of IL-4 (mouse) and IL-13 (rat and mouse) in kidney allografts 7 days after transplantation by LXR is analogous to published data that LXR activation can promote polarization of T cells to Th2 response. ${ }^{29}$ In the chronic phase of allograft rejection no evidence of increased alternative macrophage activation could be evidenced in kidney allografts. One explanation for that might be the overall reduced number of macrophages as well as cytokine levels by LXRs at this later time point.

In conclusion, our studies have shown that LXR activation by the synthetic ligand GW3965 could prevent chronic renal allograft damage. In addition, our data indicated a relevant role specifically of macrophage $\operatorname{LXR} \alpha$ in the suppression of chronic renal allograft damage.

\section{References}

1. Yates PJ, Nicholson ML: The aetiology and pathogenesis of chronic allograft nephropathy. Transpl Immunol 2006, 16:148-157

2. Joosten SA, Sijpkens YW, van Kooten C, Paul LC: Chronic renal allograft rejection: pathophysiologic considerations. Kidney Int 2005, 68:1-13

3. Wyburn KR, Jose MD, Wu H, Atkins RC, Chadban SJ: The role of macrophages in allograft rejection. Transplantation 2005, 80:16411647

4. Martinez FO, Helming L, Gordon S: Alternative activation of macrophages: an immunologic functional perspective. Annu Rev Immunol 2009, 27:451-483

5. Wang Y, Wang YP, Zheng G, Lee VW, Ouyang L, Chang DH, Mahajan D, Coombs J, Wang YM, Alexander SI, Harris DC: Ex vivo programmed macrophages ameliorate experimental chronic inflammatory renal disease. Kidney Int 2007, 72:290-299

6. Pesce JT, Ramalingam TR, Mentink-Kane MM, Wilson MS, EI Kasmi KC, Smith AM, Thompson RW, Cheever AW, Murray PJ, Wynn TA: Arginase-1-expressing macrophages suppress Th2 cytokine-driven inflammation and fibrosis. PLoS Pathog 2009, 5:e1000371

7. Dehmel S, Wang S, Schmidt C, Kiss E, Loewe RP, Chilla S, Schlöndorff D, Gröne HJ, Luckow B: Chemokine receptor Ccr5 deficiency induces alternative macrophage activation and improves long-term renal allograft outcome. Eur J Immunol 2010, 40:267-278

8. Schultz JR, Tu H, Luk A, Repa JJ, Medina JC, Li L, Schwendner S, Wang S, Thoolen M, Mangelsdorf DJ, Lustig KD, Shan B: Role of LXRs in control of lipogenesis. Genes Dev 2000, 14:2831-2838
9. Collins JL, Fivush AM, Watson MA, Galardi CM, Lewis MC, Moore LB Parks DJ, Wilson JG, Tippin TK, Binz JG, Plunket KD, Morgan DG, Beaudet EJ, Whitney KD, Kliewer SA, Willson TM: Identification of a nonsteroidal liver $\mathrm{X}$ receptor agonist through parallel array synthesis of tertiary amines. J Med Chem 2002, 45:1963-1966

10. Repa JJ, Mangelsdorf DJ: The liver X receptor gene team: potential new players in atherosclerosis. Nat Med 2002, 8:1243-1248

11. Bensinger SJ, Bradley MN, Joseph SB, Zelcer N, Janssen EM, Hausner MA, Shih R, Parks JS, Edwards PA, Jamieson BD, Tontonoz P. LXR signaling couples sterol metabolism to proliferation in the acquired immune response. Cell 2008, 134:97-111

12. Hong $C$, Tontonoz P: Coordination of inflammation and metabolism by PPAR and LXR nuclear receptors. Curr Opin Genet Dev 2008, 18: 461-467

13. Ogawa S, Lozach J, Benner C, Pascual G, Tangirala RK, Westin S, Hoffmann A, Subramaniam S, David M, Rosenfeld MG, Glass CK Molecular determinants of crosstalk between nuclear receptors and toll-like receptors. Cell 2005, 122:707-721

14. Castrillo A, Joseph SB, Marathe C, Mangelsdorf DJ, Tontonoz P: Liver $X$ receptor-dependent repression of matrix metalloproteinase- 9 expression in macrophages. J Biol Chem 2003, 278:10443-10449

15. Joseph SB, Castrillo A, Laffitte BA, Mangelsdorf DJ, Tontonoz P: Reciprocal regulation of inflammation and lipid metabolism by liver $X$ receptors. Nat Med 2003, 9:213-219

16. Marathe C, Bradley MN, Hong C, Lopez F, Ruiz de Galarreta CM, Tontonoz P, Castrillo A: The arginase II gene is an anti-inflammatory target of liver X receptor in macrophages. J Biol Chem 2006, 281: 32197-32206

17. Teupser D, Kretzschmar D, Tennert C, Burkhardt R, Wilfert W, Fengler D, Naumann R, Sippel AE, Thiery J: Effect of macrophage overexpression of murine liver $X$ receptor-alpha (LXR-alpha) on atherosclerosis in LDL-receptor deficient mice. Arterioscler Thromb Vasc Biol 2008, 28:2009-2015

18. Adams J, Kiss E, Arroyo AB, Bonrouhi M, Sun Q, Li Z, Gretz N, Schnitger A, Zouboulis CC, Wiesel M, Wagner J, Nelson PJ, Gröne $\mathrm{HJ}$ : 13-cis retinoic acid inhibits development and progression of chronic allograft nephropathy. Am J Pathol 2005, 167:285-298

19. Bedke J, Kiss E, Schaefer L, Behnes CL, Bonrouhi M, Gretz N, Horuk R, Diedrichs-Moehring M, Wildner G, Nelson PJ, Gröne HJ: Beneficial effects of CCR1 blockade on the progression of chronic renal allograft damage. Am J Transplant 2007, 7:527-537

20. Li N, Rivéra-Bermúdez MA, Zhang M, Tejada J, Glasson SS, CollinsRacie LA, Lavallie ER, Wang Y, Chang KC, Nagpal S, Morris EA, Flannery CR, Yang Z: LXR modulation blocks prostaglandin E2 production and matrix degradation in cartilage and alleviates pain in a rat osteoarthritis model. Proc Natl Acad Sci U S A 2010, 107:3734-3739

21. Wang S, Schmaderer C, Kiss E, Schmidt C, Bonrouhi M, Porubsky S, Gretz N, Schaefer L, Kirschning CJ, Popovic ZV, Gröne HJ: Recipient Toll-like receptors contribute to chronic graft dysfunction by both MyD88- and TRIF-dependent signaling. Dis Model Mech 2010, 3:92-103

22. Keppler A, Gretz N, Schmidt R, Kloetzer HM, Groene HJ, Lelongt B, Meyer M, Sadick M, Pill J: Plasma creatinine determination in mice and rats: an enzymatic method compares favorably with a highperformance liquid chromatography assay. Kidney Int 2007, 71: 74-78

23. Kiss E, Adams J, Grone HJ, Wagner J: Isotretinoin ameliorates renal damage in experimental acute renal allograft rejection. Transplantation 2003, 76:480-489

24. Weischenfeldt J, Porse B: Bone marrow-derived macrophages (BMM): isolation and applications. CSH Protoc 2008; doi:10.1101/pdb.prot5080

25. Gersuk GM, Razai LW, Marr KA: Methods of in vitro macrophage maturation confer variable inflammatory responses in association with altered expression of cell surface dectin-1. J Immunol Methods 2008, 329:157-166

26. Porubsky S, Wang S, Kiss E, Dehmel S, Bonrouhi M, Dorn T, Luckow B, Brakebusch C, Gröne HJ: Rhoh deficiency reduces peripheral T-cell function and attenuates allogenic transplant rejection. Eur J Immunol 2011, 41:76-88

27. Chomczynski $P$, Sacchi N: Single-step method of RNA isolation by acid guanidinium thiocyanate-phenol-chloroform extraction. Anal Biochem 1987, 162:156-159 
28. Chisholm JW, Hong J, Mills SA, Lawn RM, Jeffrey W: The LXR ligand T0901317 induces severe lipogenesis in the $\mathrm{db} / \mathrm{db}$ diabetic mouse. $J$ Lipid Res 2003, 44:2039-2048

29. Geyeregger R, Shehata M, Zeyda M, Kiefer FW, Stuhlmeier KM Porpaczy E, Zlabinger GJ, Jäger U, Stulnig TM: Liver X receptors interfere with cytokine-induced proliferation and cell survival in normal and leukemic lymphocytes. J Leukoc Biol 2009, 86:1039-1048

30. Vedin LL, Lewandowski SA, Parini P, Gustafsson JA, Steffensen KR: The oxysterol receptor LXR inhibits proliferation of human breast cancer cells. Carcinogenesis 2009, 30:575-579

31. von Toerne C, Schmidt C, Adams J, Kiss E, Bedke J, Porubsky S, Gretz N, Lindenmeyer MT, Cohen CD, Gröne HJ, Nelson PJ: Wnt pathway regulation in chronic renal allograft damage. Am J Transplant 2009, 9:2223-2239

32. White $\mathrm{E}$, Hildemann $\mathrm{WH}$, Mullen $\mathrm{Y}$ : Chronic kidney allograft reactions in rats. Transplantation 1969, 8:602-617

33. Blaschke F, Leppanen O, Takata Y, Caglayan E, Liu J, Fishbein MC Kappert K, Nakayama KI, Collins AR, Fleck E, Hsueh WA, Law RE, Bruemmer D: Liver $\mathrm{X}$ receptor agonists suppress vascular smooth muscle cell proliferation and inhibit neointima formation in ballooninjured rat carotid arteries. Circ Res 2004, 95:e110-e123
34. Hultén LM, Lindmark H, Diczfalusy U, Björkhem I, Ottosson M, Liu $Y$, Bondjers G, Wiklund O: Oxysterols present in atherosclerotic tissue decrease the expression of lipoprotein lipase messenger RNA in human monocyte-derived macrophages. J Clin Invest 1996, 97:461-468

35. Rowe $\mathrm{AH}$, Argmann CA, Edwards JY, Sawyez CG, Morand $\mathrm{OH}$ Hegele RA, Huff MY: Enhanced synthesis of the oxysterol 24(S),25epoxycholesterol in macrophages by inhibitors of 2,3-oxidosqualene: lanosterol cyclase. Circ Res 2003, 93:717-725

36. Shibata N, Glass CK: Regulation of macrophage function in inflammation and atherosclerosis. J Lipid Res 2009, 50(Suppl):S277S281

37. Ricardo SD, van Goor H, Eddy AA: Macrophage diversity in renal injury and repair. J Clin Invest 2008, 118:3522-3530

38. Varin A, Gordon S: Alternative activation of macrophages: immune function and cellular biology. Immunobiology 2009, 214:630-641

39. Porcheray F, Viaud S, Rimaniol AC, Léone C, Samah B, DereuddreBosquet N, Dormont D, Gras G: Macrophage activation switching: an asset for the resolution of inflammation. Clin Exp Immunol 2005 , 142:481-489 